Reprod. Nutr. Dévelop., 1986, 26 (1 B), 161-179.

\title{
Influence of substrate and microbial interaction on efficiency of rumen microbial growth
}

D. DEMEYER ( ${ }^{(1)}\left({ }^{2}\right)$, C. VAN NEVEL $\left({ }^{1}\right)$

(1) Onderzoekscentrum voor Voeding, Veeteelt en Vleestechnologie Proefhoevestraat 10, $9230 \mathrm{Melle}$, Belgium.

(2) Instituut Biotechnoligie, V.U.B., 1050, Brussel, Belgium.

Summary. Microbial $\mathrm{N}$ produced in the rumen and flowing to the duodenum $\left(\mathrm{N}_{\mathrm{i}}\right)$ is related to the total amount of OM fermented or apparently digested in the rumen $\left(O M_{\mathrm{f}}\right)$. This relationship, best expressed as microbial $\mathrm{N}$ yield $\left(\mathrm{gN}_{\mathrm{i}} / \mathrm{kgOM}_{\mathrm{f}}\right)$, is affected mainly by the physical and chemical properties of feed carbohydrates and the amounts ingested. These factors influence yields at three levels of increasing complexity :

1) Bacterial fermentation within one compartment following the continuous culture model. Fermentation pattern as such does not seem to affect yields. High fermentation rates are associated with lactate production, low methane production and transient polysaccharide synthesis. These effects induce acidification and lower yields, partly compensated by faster growth.

2) Protozoal action, determined by the presence of sequestration spaces provided mainly by roughage diets. The presence of protozoa depresses microbial $\mathrm{N}$ yield but allows more complete fibre digestion.

3) Compartmentation and differential passage. With roughage diets, optimal microbial $\mathbf{N}$ yield seems to require well developed microbial compartmentation, involving a large proportion of microbes in a large-particle pool with a slow turnover, balanced by a small proportion in liquid, small-particle pools with a fast turnover. Such a situation is associated with long roughage feeding.

It is hypothesized that microbial $\mathrm{N}$ yields in the rumen may vary between two extremes which are associated with the feeding of long roughage on the one hand or with concentrate (starch) feeding on the other.

\section{Rumen microbial growth : introductory remarks.}

With most diets, at least half the protein reaching the ruminant duodenum is microbial protein, produced during the digestion of feed in the rumen. This amount can be related to the amount of organic matter fermented in the rumen $\left(O M_{f}\right)$, determined as the net disappearence of $O M$ between the rumen and duodenum and involving some assumptions (Egan, 1974). Both, $N$ incorporated into microbial crude protein and leaving the rumen $\left(N_{i}\right)$, and $O M_{f}$ can be estimated in vivo using cannulated animals and markers for the determination of digesta flow and microbial N. Apart from differences in cell composition (Armstrong, 1980), the relationship of $\mathrm{N}_{\mathrm{i}}$ to $\mathrm{OM}_{\mathrm{f}}$ reflects the evident limitation of 
microbial growth by energy liberated during rumen fermentation. However, the gross energy content of microbial $O M\left(O M_{m}\right)$ is equal to that of feed carbohydrate and protein : the enthalpy change in the conversion of feed $O M$ to $O M_{m}$ is close to zero and the need for energy is mainly determined by a decrease in entropy. The energetic efficiency of microbial $N$ incorporation $(E)$ or microbial $N$ yield as a measure of microbial growth yield is thus best expressed as $E=g N_{i} / \mathrm{kgOM}_{\mathrm{f}}$ (Demeyer and $\operatorname{Van}$ Nevel, 1976) and not as $E=\mathrm{gN}_{\mathrm{i}} / \mathrm{kg}\left(O \mathrm{M}_{\mathrm{f}}+\mathrm{OM}_{\mathrm{m}}\right.$ ), a correction still used by some authors (Crawford et al., 1980 ; Zinn et al., 1981). Also, the error involved in the determination of $N_{i}$ is introduced into both the numerator and denominator in the latter expression of $\mathrm{E}$. It can be shown that $y=80 x /(x+80)$, with $y=g N_{i} / k g\left(O M_{f}+O M_{m}\right)$ and $x=E=g N_{i} / k O_{f}$ and $\mathrm{OM}_{\mathrm{m}}$ containing $0.08 \mathrm{~N}$. Figure 1 shows that $Y$ is less susceptible than $E$ to changes in the efficiency of use of fermentation energy.

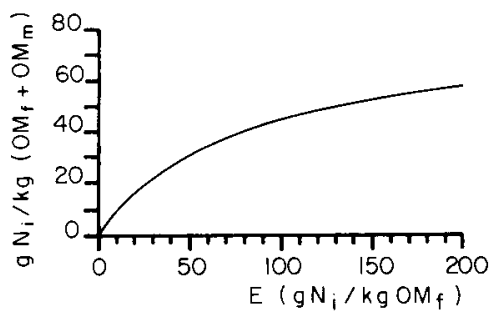

FIG. 1. - Relation between $\mathrm{E}=\mathrm{gN}_{\mathrm{i}} / \mathrm{kgOM}_{\mathrm{f}}$ and $\mathrm{gN}_{\mathrm{i}} / \mathrm{kg}\left(\mathrm{OM}_{\mathrm{f}}+\mathrm{OM}_{\mathrm{m}}\right)$ for $\mathrm{OM}_{\mathrm{m}}$ containing $0.08 \mathrm{~N}$.

Numerous determinations of $E$ have been carried out in vivo and values vary between 10 and 70 (Van Nevel and Demeyer, 1977) (Cummins et al., 1983) around a mean of about 30, a figure introduced in systems for ruminant feed protein evaluation (Jarrige et al., 1978 ; Roy et al., 1977). Although experimental error is an important factor in variability (Faichney, 1975 ; Sutton, 1979 ; Ling and Buttery, 1978), recent data have permitted the conclusion that, provided rumen degradable protein is not a limiting factor of microbial growth, diets largely based on concentrates and on silage give lower $E$ values than mixed diets (Tamminga, 1983) or forage diets (Van Nevel and Demeyer, 1983 ; Van Soest, 1982). Contradictory results however have also been published (Cummins et al., 1983) in relation to level (Tamminga, 1978; Zinn and Owens, 1983) and frequency (Hungate et al., 1971 ; Brandt et al., 1981) of feeding and protein supplementation (Redman et al., 1980 ; McAllan and Smith, 1984). Even breed may affect $E$ values (Kennedy, 1982). Table 1 summarizes some recent results (varying between the extremes of 66 and 13) obtained on concentrate (Cummins et al., 1983) and tropical forage (Kennedy, 1982), respectively. It should be realized that in order to interpret differences, rumen microbial $N$ yield, $E$, must be rationalized in models of increasing complexity. The continuous culture model of bacterial growth in one compartment has been used extensively (Harrison and McAllan, 1980), although it does not account for two important characteristics of the rumen emphasized in more recent work :

1) The presence of protozoa as predators in the rumen: The presence of protozoa in the rumen is responsible for bacterial turnover amounting to $20-50 \%$ of bacterial N (Tamminga, 1980). 


\section{TABLE 1}

Rumen microbial $N$ yields in vivo with different diets.

\begin{tabular}{|c|c|c|c|}
\hline $\begin{array}{l}\text { Main diet } \\
\text { component }\end{array}$ & Animals & $\begin{array}{l}\text { Microbial } N \\
\text { yield } \\
\left(\mathrm{gN}_{\mathrm{i}} / \mathrm{kgOM}_{\mathrm{f}}\right)\end{array}$ & Reference \\
\hline $\begin{array}{l}\text { Sugars. } \\
\text { Sugar beet } \\
\text { Molasses } \\
\text { Sucrose }\end{array}$ & $\begin{array}{l}\text { dairy cows } \\
\text { sheep } \\
\text { sheep }\end{array}$ & $\begin{array}{l}24 \\
26 \\
23\end{array}$ & $\begin{array}{l}\text { Hvelplund \& Moeller, } 1978 . \\
\text { Demeyer \& Van Nevel, } 1978 . \\
\text { Hart \& Orskov, } 1979 .\end{array}$ \\
\hline $\begin{array}{l}\text { Concentrates. } \\
\text { Starch } \\
\text { Barley + flaked maize } \\
\text { Corn } \\
\text { Corn L. I. } \\
\text { H. I. } \\
\text { Barley } \\
\text { Barley } \\
\text { Corn } \\
\text { Barley }\end{array}$ & $\begin{array}{l}\text { sheep } \\
\text { sheep } \\
\text { steers } \\
\text { steers } \\
\text { steers } \\
\text { sheep } \\
\text { steers } \\
\text { sheep }\end{array}$ & $\begin{array}{l}24 \\
15 \\
66 \\
24 \\
31 \\
23 \\
23-27 \\
27 \\
30\end{array}$ & $\begin{array}{l}\text { Hart \& Orskov, } 1979 . \\
\text { Chamberlain \& Thomas, } 1979 . \\
\text { Cummins et al., } 1983 . \\
\text { Zinn \& Owens, } 1983 . \\
\text { Whitelaw et al., } 1984 . \\
\text { Ling et al., 1983. } \\
\text { Zinn \& Owens, 1983a. } \\
\text { Mathers \& Miller, 1981. }\end{array}$ \\
\hline $\begin{array}{l}\text { Roughage. } \\
\text { Poor quality } \\
\text { Oaten chaff } \\
\text { Paper } \\
\text { Tropical pasture hay } \\
\text { Silage (unsupplemented) } \\
\text { Maize silage } \\
\text { Wilted silage } \\
\text { Grass silages } \\
\text { Maize silage } \\
\text { Forage } \\
\text { Ground brome grass } \\
\text { Alkali-treated straw } \\
\text { Alkali-treated straw } \\
\text { Alkali-treated straw } \\
\text { Fresh forage } \\
\text { Alfalfa hay } \\
\text { Chopped hay } \\
\text { Chopped hay } \\
\text { Lucerne hay }\end{array}$ & $\begin{array}{l}\text { steers } \\
\text { sheep } \\
\text { steers } \\
\text { calves } \\
\text { cattle + sheep } \\
\text { cattle + sheep } \\
\text { dairy cows } \\
\text { sheep } \\
\text { sheep } \\
\text { sheep } \\
\text { dairy cows } \\
\text { sheep } \\
\text { steers Brahman x } \\
\text { sheep Hereford } \\
\text { steers } \\
\text { sheep }\end{array}$ & $\begin{array}{l}21 \\
20 \\
13 \\
19 \\
19 \\
22-27 \\
10-22 \\
21-22 \\
36-51 \\
33 \\
36 \\
30 \\
37 \\
29 \\
21 \\
30 \\
28 \\
39\end{array}$ & $\begin{array}{l}\text { Redman et al., } 1980 . \\
\text { Offer et al., } 1978 . \\
\text { Kennedy, 1982. } \\
\text { Cottrill et al., 1982. } \\
\text { Meggison et al., 1979. } \\
\text { Chamberlain \& Thomas, } 1980 . \\
\text { Teller \& Godeau, 1984. } \\
\text { Kennedy \& Milligan, } 1978 . \\
\text { Hart \& Orskov, 1979. } \\
\text { Harmeyer et al., 1980. } \\
\text { Moeller \& Hvelplund, } 1982 . \\
\text { Moeller \& Hvelplund, } 1982 . \\
\text { Kennedy, 1982. } \\
\text { Kennedy, 1982. } \\
\text { Chamberlain \& Thomas, } 1979 . \\
\text { Zinn \& Owens, 1983a. } \\
\text { Mathers \& Miller, 1981. }\end{array}$ \\
\hline $\begin{array}{l}\text { Mixed diets. } \\
\text { Hay + corn (chopped) } \\
\text { (ground) } \\
\text { Hay + barley } \\
\text { Hay + barley + maize } \\
\text { Hay + barley } \\
\text { Lucerne hay + barley } \\
\text { Wheat starch + paper } \\
\text { Roughage + concentrate } \\
\text { - High intake } \\
\text { - Low intake } \\
\text { Roughage + concentrate } \\
\text { Roughage + concentrate }\end{array}$ & $\begin{array}{l}\text { steers } \\
\text { sheep } \\
\text { sheep } \\
\text { sheep } \\
\text { sheep } \\
\text { sheep } \\
\text { dairy cows } \\
\text { dairy cows } \\
\text { dairy cows } \\
\text { dairy cows }\end{array}$ & $\begin{array}{l}29 \\
34 \\
26 \\
33-36 \\
27-34 \\
36-43 \\
48 \\
\\
24-49 \\
27-56 \\
35 \\
35\end{array}$ & $\begin{array}{l}\text { Cummins et al., } 1983 . \\
\text { Cummins et al., } 1983 . \\
\text { Whitelaw et al., 1984. } \\
\text { Chamberlain \& Thomas, } 1979 . \\
\text { Ushida et al., 1984. } \\
\text { Mathers \& Miller, } 1981 . \\
\text { Offer et al., 1978. } \\
\text { Tamminga, 1978. } \\
\text { Tamminga, 1978. } \\
\text { Meggison et al., } 1979 . \\
\text { Harmeyer et al., } 1981 .\end{array}$ \\
\hline
\end{tabular}


2) Compartmentation and differential retention of rumen contents: The need of the microbes to attach to insoluble feed particles before onset of fermentation and during fermentation has emphasized the importance of the compartmentation of the rumen population (Cheng and Costerton, 1979). It is clear that on the average, microbes leave the rumen at fractional rates $\left(k_{m}\right)$ which are less than liquid phase fractional outflow or dilution rate $\left(k_{1}\right)$ (fractional rate $=$ actual outflow in $\mathrm{g}$ or $\mathrm{ml} / \mathrm{h}$ divided by rumen total pool size in $\mathrm{g}$ or $\mathrm{ml}$ ), as shown by Hungate et al. (1971) and concluded by Mathers and Miller (1981) from data in the literature.

Obviously the composition and physical properties of feed determine $E$ at three levels of complexity:

1) continuous or batch culture within each compartment ;2) protozoal predation ;

3) microbial distribution over the compartments.

\section{Microbial growth of mixed rumen bacteria within one compartment.}

This relatively simple model has allowed comparisons of theoretical growth yields $Y_{A T P}^{\text {theor. }}(g$ cell $D M / m o l ~ A T P)$ with practical values of $Y_{S}(g$ cell $D M / m o l$ substrate fermented). Calculation of $\boldsymbol{n}$ (moles ATP $/ \mathrm{mol}$ substrate fermented) from known biochemical pathways allows calculation of $Y_{\text {ATP, }}$, and such values are always lower than $Y_{\text {ATP }}^{\text {theor. }}$ This difference can be explained since a significant proportion of ATP is required for maintenance and varies with fractional growth rate, $\mu$, following the Pirt-Shouthamer equation (Shouthamer and Bettenhausen, 1973). It is not alwavs clear however if energy costs are to be incorporated in the calculation of $Y_{A T P}^{\text {theor. }}$ or to be defined as maintenance. Energy cost for nutrient transport (Hespell and Bryant, 1979) or the degree of coupling between energy yield and biosynthesis (Thauer and Kröger, 1983) are examples of this controversy. Furthermore, as bacteria are known to vary the degree of coupling as well as ATP yield in response to environmental conditions (Thauer and Kröger, 1983), any calculation of $Y_{A T P}$ is bound to be at best a reasonable estimate. Application of the Pirt-Stouthamer model indicates however that a double reciprocal plot of $Y_{S} v s \mu$ is linear when ATP yield does not change with $\mu$ (Hespell and Bryant, 1979).

1.1. Fermentation pattern and $\mathrm{Y}_{\mathrm{ATP}}$ estimation with mixed rumen bacteria. - Mixed rumen bacteria are considered to be mainly strict anaerobes generating energy from carbohydrate fermentation through substrate level phosphorylation (SLP), giving $4 \mathrm{~mol}$ ATP/mol hexose monomer completely fermented to acetate. Removal of the electrons in methanogenesis and eventual phosphorolytic cleavage of the disaccharides generate additional ATP. Disposing of reducing equivalents $(2 \mathrm{H})$ in end-products other than methane may result in lower ATP yields because acetate precursors are removed from SLP and used as electron acceptors in lactate or ethanol production (Wolin and Miller, 1983). In mixed rumen microbes, $2 \mathrm{H}$ may be disposed of in propionate production at the expense of methanogenesis (Demeyer and Van Nevel, 1975), and it is now 
accepted that propionate production following the succinate pathway generates $1 \mathrm{~mol}$ ATP/mol propionate by anaerobic electron transport phosphorylation (ETP) (Thauer and Kröger, 1983). ETP may be a special example of energy generation by the separation of electrons and protons across membranes, generating a charge separation utilized for ATP synthesis by a proton translocating ATPase. A similar electrochemical gradient may result from the outflow of fermentation acids coupled with a proton flux (Erfle et al., 1984 ; Thauer et al., 1977).

The importance of anaerobic ETP in the fermentation of mixed rumen bacteria may be assessed from a comparison of total microbial growth efficiency determined in short-time batch incubations using carbohydrate and pyruvate as substrates. Yields (E) are calculated from ${ }^{32} \mathrm{PO}_{4}^{3}$ incorporation and are not affected by cell lysis brought about, e.g., by protozoal ingestion of bacteria (Van Nevel and Demeyer, 1977 ; Harmeyer and Güldenhaupt, 1980).

From known biochemical pathways it is obvious that molar ATP yields from ETP (ATP ETP) are equal with both substrates, where as we can calculate molar ATP yield from SLP (ATP SLP $_{1}$ for both substrates with reasonable accuracy (Tamminga, 1979). The difference in total microbial $N$ yields (calculation in Van Nevel and Demeyer, 1977) between the two substrates obviously occurs because of a different SLP only. This allows calculation of $\mathrm{gN}_{\mathrm{i}} / \mathrm{mol}$ ATP (table 2 ). In table 2 , this difference is $47-27=20 \mathrm{gN}_{\mathrm{i}} / \mathrm{kg} \mathrm{OM}$ derived from 12.5 moles ATP $/ \mathrm{kg} \mathrm{OM}$ generated by SLP. From these values it can be calculated that $\mathrm{gN}_{\mathrm{i}} / \mathrm{mol}$ ATP $=20 / 12.5=1.6$. The latter value allows calculation of the total ATP yield (SLP + ETP) from both substrates as $\left(\mathrm{gN}_{\mathrm{i}} / \mathrm{kg} \mathrm{OM}_{\mathrm{f}}\right) /\left(\mathrm{gN}_{\mathrm{i}} / \mathrm{mol}\right.$ ATP), giving 29.4 and 16.9 for carbohydrates and pyruvate, respectively. Subtracting SLP ATP-yield from total ATP yield gives an estimated yield of 5.9 moles of ATP from ETP.

The data are obviously affected by differences in cell composition (e.g. differences in polysaccharide synthesis) but do suggest that ETP is less important than SLP (table 2). Assuming $8 \% \mathrm{~N}$ in bacterial DM, YATP $=20$ can be calculated (table 2 ) in reasonable agreement with the value $Y^{\max }=25$, corrected for the energy cost of nutrient transport and monomer synthesis (Hespell and

TABLE 2

Estimation of ATP yield from ETP and of $\mathrm{Y}_{\mathrm{ATP}}$ in mixed rumen bacteria ${ }^{1}$.

\begin{tabular}{|c|c|c|c|c|}
\hline \multirow{2}{*}{ Substrate } & \multicolumn{2}{|c|}{ ATP yield (moles $/ \mathrm{kgOM}_{\mathrm{f}}$ ) from } & \multicolumn{2}{|c|}{ Total growth efficiency } \\
\hline & $S L P^{2}$ & ETP $^{4}$ & $\mathrm{gN}_{\mathrm{i}} / \mathrm{kgOM}^{1}$ & $Y_{\text {ATP }}^{3}$ \\
\hline Cellobiose + maltose & 23.5 & 5.9 & 47 & \\
\hline Pyruvate & 11.0 & 5.9 & 27 & \\
\hline Difference & $12.5\langle 1\rangle$ & - & $20(2)$ & 20 \\
\hline
\end{tabular}

1 Data from Demeyer and Van Nevel, 1979. ${ }^{2}$ Calculated from biochemistry (Tamminga, 1979) from carbohydrate monomer Mol. Wt. = 162 and molar acetate, propionate and butyrate proportions of 70,20 and 10 , respectively. ${ }^{3}$ Calculated from (2) and (1), assuming that bacterial DM contains $0.08 \mathrm{~N} .{ }^{4}$ Calculated from $\mathrm{gN}_{\mathrm{i}} / \mathrm{kg} \mathrm{OM}$, and SLP as described in the text. 
Bryant, 1979). The data are in line with the contention that maximal fermentation energy yield is obtained when methanogenesis, as electron sink not involving acetate precursors, is maximal (Hungate, 1963). Lowered $E$ values when methanogenesis is inhibited in batch incubations of mixed rumen bacteria with corresponding shifts to propionate production (Van Nevel and Demeyer, 1981) also support this theory.

However, rumen contents from different sheep with various propionate proportions in the end-products of short-term batch incubations showed no difference in microbial $\mathbf{N}$ yields (Demeyer and Van Nevel, 1975a). Increasing $\mu$ (fractional outflow rate) in continuous cultures of mixed rumen bacteria (absence of protozoa) also changes the fermentation pattern, but linear plots of $\frac{1}{\mathrm{Y}} \mathrm{vs} \frac{1}{\mu}$ are apparent (fig. 2) (Van Nevel and Demeyer, 1979 ; Isaacson et al., 1975 ; Hoover et al., 1982). This indicates a constant ATP yield although large differences in the relative proportions of methane and propionate are observed.

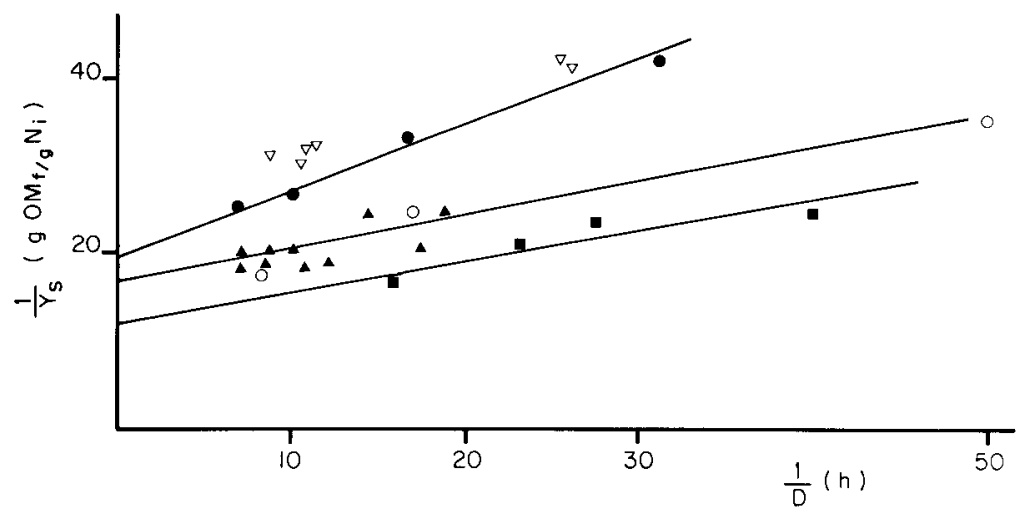
FIG. 2. - Dote $\left(\mathrm{h}^{-1}\right)$.

Data from continuous cultures: - Van Nevel \& Demeyer (1979); $\bigcirc$ Isaacson et al. (1975) ; - Hoover et al. (1982). Data were recalculated and corrected for $15 \%$ overestimation of microbial RNA. Particle passage rates are used.

Data obtained in vivo : $\nabla$ Harrison et al. (1975) ; A Kennedy et al. (1976), Kennedy and Milligan (1978). Both liquid and particle outflow rates are shown.

From the mean intercepts with the ordinate in figure 2 , a mean value for $Y_{\mathrm{s}}^{\max }=62.8 \mathrm{~g} \mathrm{~N}_{\mathrm{i}} / \mathrm{kg} \mathrm{OM}$ can be calculated. Assuming ATP yield to be 29.4 moles $/ \mathrm{kg} \mathrm{OM}_{\mathrm{F}}$ (table 2) and that bacterial DM contains $0.08 \mathrm{~N}$, it can be calculated that $Y_{A T P}^{\max }=27$, a reasonable estimate (Hespell and Bryant, 1979).

Results suggest that short-term inhibition of methanogenesis with a shift to propionate production lowers ATP yield. A mixed flora seems to be able to adapt to a high propionate fermentation however, without loss of energetic efficiency: lowered energy yield through acetokinase and methanogenesis is effectively replaced by energy yield from propionate production. The intercellular succinate transport involved in the two-organism system of rumen propionate production (Wolin, 1979), as well as methylmalonyl-coA decarboxylation, may be adapted systems for extra energy generation (Erfle et al., 1984). The relative unimportance 
of fermentation pattern in the energetic efficiency of rumen fermentation is also suggested by the finding that propionate as well as acetate fermentation types can be associated with higher yields of microbial $\mathrm{N}$ in vivo (Harisson et al., 1975 ; Kennedy et al., 1976). Propionate production following the acrylate pathway would not generate ATP however and this pathway prevails at low $\mathrm{pH}$ values (Durand, 1982), whereas changes in the degree of coupling as well as changes in ATP yield with alterations in the fermentation pattern can be involved (Thauer and Kröger, 1983). Because of the latter effects, the use of $Y_{\text {ATP }}$ in rumen fermentation is to be discouraged.

A last but important point is the question of rumen anaerobiosis. Rumen metabolism is normally regarded as being extremely anaerobic (Russel and Hespell, 1981) but mixed rumen microbes can consume $\mathrm{O}_{2}$ with stoichiometric and reversible inhibition of methanogenesis (Demeyer et al., 1972 ; Scott et al., 1983).

Recently, Czerkawski and Clapperton (1984) reported that rumen contents may consume $100 \mathrm{ml} \mathrm{O} /$ day/l. Similar quantities were consumed in short-term batch incubations: reduced endproduct formation was inhibited according to stoichiometry, but substrate disappearance and total microbial $\mathrm{N}$ yield was not affected (Demeyer et al., 1984). In this respect, it may be significant that facultative anaerobic Bacillus sp. may contribute to rumen fibre digestion, e.g. by the presence of $\alpha$-L-arabinofuranosidase (Williams and Withers, 1983).

\subsection{Effest of energy source. - The major sources of fermentation-derived} energy in the rumen are carbohydrates and proteins, lipids being relatively insensitive to microbial attack, apart from lipolysis, fatty acid hydrogenation and incorporation (Demeyer, 1973 ; Demeyer et al., 1978).

1.2.1. Carbohydrates. - Feed carbohydrates can be broadly classified into plant cell wall or structural carbohydrates $(\beta$-glycosidic insoluble cellulose and hemicelluloses) and storage or non structural carbohydrates ( $\alpha$-glycosidic, partly soluble starches and soluble oligosaccharides or sugars) (Tamminga, 1979).

Non-structural carbohydrates are rapidly fermented in the rumen and the concomittant excess of pyruvate production shifts fermentation to propionate and, ultimately, to lactate production (see e.g. Silley and Armstrong, 1984). Individual sugars show small differences in fermentation pattern (Van Nevel et al., 1972 ) but this pattern is mainly related to rate of fermentation and thus, to rate of substrate supply (Demeyer and Van Nevel, 1975). Fermentation rate, irrespective of fermentation pattern, reflects growth rate and its increase augments $E$ (fig. 2) (Demeyer and Van Nevel, 1975a), unless the need to dispose rapidly of ATP increases lactate production, decreasing SLP and, thus, E (Van Nevel and Demeyer, 1977). Concomittant increases in polysaccharide synthesis and decreases in $\mathrm{pH}$ may also lower $\mathrm{E}$. Microbial growth is very sensitive to changes in $\mathrm{pH}$ (Hoover et al., 1984), possibly because of interference with the generation of proton motive force, a low $\mathrm{pH}$ reducing ETP (Erfle et al., 1984). Such effects help to explain the low microbial $N$ yields observed with high sugar and starch diets (table 1). Increasing the frequency of feeding could prevent these 
fermentation bursts and result in higher $E$ values (Hungate et al., 1971), but this effect is not always observed (Brandt et al., 1981). Differences in rates of starch fermentation between rolled barley and ground maize are probably responsible for differences in the microbial $\mathrm{N}$ yields observed with these diets (Oldham et al., 1979).

Structural carbohydrate fermentation requires preliminary attachment of the microbes to dietary fibre, resulting in a time-lag before the onset of fermentation (Cheng et al., 1977). Synthesis of the adhering glycocalyx fibres obviously requires energy and one would expect $E$ to be lower on structural carbohydrates than on starches, when corrected for differences in growth rate. Stern et al. (1978) determined $E$ in vitro with increasing inclusion of cellulose into a starch substrate. Other factors (fermentation and growth rate, fractional outflow rate, protozoal count and $\mathrm{pH}$ ) being constant, the results clearly show that $E$ is lowered with increasing cellulose inclusion (table 3). Clearly, this result is opposite to animal data showing that higher $E$ values are obtained with roughage than with concentrate diets (table 1). Besides the effect of fermentation bursts with concentrate diets, effects at the level of protozoal predation and compartmentation are probably involved, as discussed further on.

TABLE 3

Effect of cellulose on rumen microbial $N$ yield in continuous culture.

\begin{tabular}{lccc}
\hline Substrate $(\%$ of diet) & & & \\
Corn starch & 4.0 & 18.0 & 31.4 \\
Solca floc. & 29.9 & 15.0 & 0 \\
$\mathrm{OM}_{\mathrm{F}}(\mathrm{g} / 24 \mathrm{~h})^{2}$ & 23.4 & 24.9 & 24.4 \\
$\mathrm{~N}_{\mathrm{i}}(\mathrm{g} / 24 \mathrm{~h})$ & 0.95 & 1.19 & 1.33 \\
$\mathrm{gN}_{\mathrm{i}} / \mathrm{kg} \mathrm{OM}$ & 40.6 & 47.8 & 54.5 \\
\hline
\end{tabular}

1 Data from Stern et al. (1978). Average values for $k_{1}=0.060, k_{s}=0.025, p H=6.60$, protozoa $=10^{4} / \mathrm{ml} .{ }^{2}$ Calculated from volatile fatty acid production.

1.2.2. Protein. - Many diets contain up to $20 \%$ protein, $70 \%$ of which is degraded in the rumen as a result of proteolysis, followed by oxidative deamination and transamination of the amino acids and fermentation of the resulting keto-acids, according to the stoichiometry of carbohydrate fermentation (Demeyer and Van Nevel, 1979). Carbohydrate availability does not affect proteolysis but lowers ammonia production (Russell et al., 1982). In line with theoretical considerations (Tamminga, 1979), microbial $N$ yields obtained using proteins as energy sources are comparable to those obtained with pyruvate and amount to only 0.50 of the yields obtained with carbohydrate as an energy source (Demeyer and Van Nevel, 1979). It is evident that the inclusion of apparently digested protein in $\mathrm{OM}_{\mathrm{f}}$ is a source of variation in $\mathrm{E}$. Therefore, and to overcome problems related to the inclusion of endogenous OM in digesta flow, Tamminga (1978) proposed to relate $N_{i}$ to the total of crude fibre and $\mathrm{N}$-free extractives apparently digested in the rumen. As only a limited part of fermentation energy is 
derived from protein, such an expression may be more appropriate, although less straightforward because more empirical analysis is necessary.

1.3. Effect of $N$ source. - It is obvious that rumen bacteria have to be supplied with sufficient $N$ (as well as with other nutrients such as $S, P$ and trace elements) to realize maximum growth under energy-limiting conditions. From $E=30$ and $a$ proportion of $0.70 \mathrm{OM}_{\mathrm{f}}$ in feed $\mathrm{OM}$ it can be calculated that feed $\mathrm{OM}$ should contain ca. $13 \%$ of rumen-degradable crude protein, similar to other estimates (Satter and Roffler, 1981). Low quality roughage diets as well as high-concentrate diets often have $N$ contents below that value, and $E$ with such diets may therefore be limited by $\mathrm{N}$ and enhanced by non-protein nitrogen supplementation (Elliott and Armstrong, 1982). However, no effect on $E$ was obtained with $N$ supplementation of low $\mathrm{N}$ roughage diets by Kropp et al. (1977, 1977a), Amos and Evans (1976), Redman et al. (1980) or Moeller and Hvelplund (1982). With high-concentrate diets, results are contradictory: $N$ supplementation either improves E (McAllan and Smith, 1984) or has no effect (Brandt et al., 1981). The contradictory results may be explained by differences in urea recycling to the rumen according to the diet: long roughage diets promote urea recycling by intensive rumination and salivation, in contrast to concentrate diets. The availability of ammonia- $\mathrm{N}$ for rumen microbial growth is reflected in rumen ammonia concentration and it has been proposed that values below $50 \mathrm{mg} \mathrm{NH}$ $\mathrm{N} / \mathrm{l}$ indicate $\mathrm{N}$-limitation of microbial growth. It is unlikely however that such concentrations limit growth as $\mathrm{NH}_{3} \mathrm{~K}_{\mathrm{s}}$ values (concentrations at which 0.50 of optimal growth is obtained) for rumen bacteria are around $1 \mathrm{mg} / \mathrm{l}$ (Hespell and Bryant, 1979). Also rumen ammonia concentration is not necessarily related to microbial intracellular ammonia concentration. Furthermore the concentrations reflect the balance of production and utilization: low values may reflect low turnover and efficient growth rather than limitation, as in the defaunated rumen discussed further on. Amino acid transport $k_{m}$ values for several anaerobic bacteria are however similar to the low values often found in the rumen, and Hespell and Bryant (1979) suggest that rumen fermentation may be uncoupled due to impaired amino acid transport into bacteria. All amino acid carbon skeletons can be synthesized in the rumen, and ammonia- $\mathrm{N}$ is incorporated by rumen bacteria through the combined action of glutamine synthetase and glutamate synthase at low ammonia concentrations (Hespell, 1983) and through glutamate dehydrogenase. Tracer experiments in vivo indicate that rates of methionine and phenylalanine synthesis may limit bacterial growth with proteinfree diets and rumen bacteria may use up to $0.80 \mathrm{~N}$ as peptide or amino acid $\mathrm{N}$, depending on the dietary protein content (Smith, 1979 ; Demeyer and Van Nevel, 1980). This does not decrease the energy cost of cell formation, as the major cost is polymerization and not monomer synthesis (Hespell and Bryant, 1979), but it may decrease transport energy expenditure as an inverse function of amino acid polymer length (Hespell and Bryant, 1979 ; Demeyer and Van Nevel, 1980). These ideas are supported by the finding that free amino acids or protein stimulate $E$ in vitro (Maeng et al., 1976 ; Cotta and Russell, 1982). The initial observation of Hume (1970) that protein stimulates $E$ in animals fed a synthetic diet has been 
confirmed (Cottrill et al., 1982 ; Elliott and Armstrong, 1982 ; McAllan and Smith, 1983, 1984) as well as contradicted (Brandt et al., 1981 ; Kropp et al., 1977, 1977a ; Amos and Evans, 1976 ; Redman et al., 1980 ; Moeller and Hvelplund, 1982) in animals receiving natural diets. The absence of an effect in the animat may be related to long rumen retention of microbes with long roughage diets ensuring sufficient recycling of microbial protein to provide the necessary supply of amino acids and peptides (Kropp et al., 1977). Also, sufficient protein should be added to prevent complete degradation of amino acids in the rumen, thus allowing their incorporation (Ben-Ghedalia et al., 1978).

\section{The presence of protozoa}

The role of protozoa in the rumen is still debated (Hobson and Wallace, 1982) and their metabolic importance considered obscure (Van Soest, 1982). It is obvious however that their presence is associated with considerable turnover of microbial $\mathrm{N}$ because of the turnover of the population of holotrichous protozoa, itself, associated with molasses feeding (Leng, 1982 ; Leng and Nolan, 1982), or the turnover of bacteria ingested by populations largely composed of entodiniomorphid protozoa (Coleman and Sanford, 1979). Such predation is probably not accounted for by Pirt-like maintenance equations (Hobson and Wallace, 1982) as it necessitates the adaptation of mathematical models for continuous culture (Smouse, 1981). The detrimental role of protozoa in rumen microbial $\mathbf{N}$ yield was speculated upon in earlier work (review in Demeyer, 1981) and demonstrated by the determination of simultaneous total synthesis and degradation of microbial matter in vitro (Van Nevel and Demeyer, 1977) using faunated and defaunated mixed rumen microorganisms (Demeyer and Van Nevel, 1979). The absence of protozoa lowered degradation and slightly increased total synthesis, resulting in a considerable increase of net synthesis (e.g. total synthesis-degradation). The efficiency of net microbial $N$ incorporation (E) was increased by defaunation, not only because of elimination of turnover due to protozoal lysis and predation, but also because of a shift to a faster-growing amylolytic flora (Kurihara et al., 1978), as indicated by the increased efficiency of total synthesis. These results obtained in vitro have recently been confirmed in a number of animal experiments and it is clear that variability in microbial $N$ vields may be determined to a large extent by variability in the number and activity of rumen protozoa, quite apart from energy yield in fermentation (Demeyer and Vervaeke, 1984). Dietary factors affecting the protozoal population have been reviewed by Demeyer (1981) and mainly relate to the physical form of feed particles, the proportion of starches and sugars and the level of feeding.

2.1. Roughage diets. - Long roughage sustains populations largely composed of entodiniomorphid protozoa in the rumen by providing sequestering spaces for the swimming protozoa. Low quality roughage is probably less beneficial to protozoa because of a shortage of easily degradable starches and sugars (Jouany, 1978). Grinding the roughage impairs sequestration, lowers protozoal count and also 
promotes retention by reducing salivation and $k_{1}$. The large protozoal populations associated with silage diets (Chamberlain and Thomas, 1980) may be due to dietary promotion of sequestration and they could be responsible for low $E$ values (table 1), although the same argument holds for long roughage diets which do not promote low $\mathrm{E}$ values.

2.2. Concentrate diets. - Restricted feeding of starch diets sustains large rumen populations of entodiniomorphid protozoa (Eadie et al., 1970) that are possibly responsible for the low $E$ values observed with such diets (Ling et al., 1983; Whitelaw et al., 1984). Higher feeding levels and/or grinding concentrate diets lowers protozoal count through acidification and increased tonicity associated with intensive fermentation, reduced salivation and lower $k_{1}$ values, although other factors may be involved (Lyle et al., 1981). Many animals on highconcentrate feeds are defaunated (Johnson, 1976) and high concentrate feeding is in fact an efficient defaunation procedure (Whitelaw et al., 1984a). The detrimental effects on $E$ values of fermentation bursts and lowered salivation associated with such diets may be partly balanced by the defaunating effect, as illustrated by a comparison of some data in the literature (table 4). Liquid diets containing large amounts of sugars sustain large populations of holotrichous protozoa because limited intake restricts fermentation intensity (Coleman, 1979).

TABLE 4

Microbial $N$ yield in faunated and defaunated animals fed high-concentrate diets.

\begin{tabular}{|c|c|c|c|}
\hline Animal & Diet & $\begin{array}{l}\text { Level of Feeding } \\
(\mathrm{kg} / \mathrm{d})\end{array}$ & $\begin{array}{l}\text { Microbial } N \text {-yield } \\
\left\{\mathrm{gN}_{\mathrm{i}} / \mathrm{kgOM}_{\mathrm{f}}\right\}\end{array}$ \\
\hline $\begin{array}{l}\text { Sheep } \\
\text { Faun }{ }^{1} \\
\text { Faun. }^{2} \\
\text { Defaun. }\end{array}$ & $\begin{array}{l}\text { Flaked maize }+ \text { dried grass } \\
\text { Starch } \\
\text { Rolled barley }\end{array}$ & $\begin{array}{l}0.4 \\
0.6 \\
0.6\end{array}$ & $\begin{array}{l}24 \\
24 \\
35-40\end{array}$ \\
\hline $\begin{array}{l}\text { Steers } \\
\text { Faun. }{ }^{4} \\
\text { Defaun. }^{5}\end{array}$ & $\begin{array}{l}\text { Oaten chaff }+ \text { molasses }+ \text { starch } \\
\text { Starch }+ \text { straw }\end{array}$ & $\begin{array}{l}3.1-3.2 \\
2.3-2.5\end{array}$ & $\begin{array}{l}16-22 \\
22-29^{6}\end{array}$ \\
\hline
\end{tabular}

${ }^{1}$ Harrison et al., $1975 ;{ }^{2}$ Hart and Orskov, $1979 ;{ }^{3}$ Mercer et al., $1980 ;{ }^{4}$ Redman et al., 1980 ;

5 McAllan and Smith, $1984 ;{ }^{6}$ Only data for $\mathrm{N}$ supplemented diet were used.

A special case is the inclusion of fat in the diet which has been observed to increase $E$ in sheep (Demeyer, 1981) and possibly in cattle (Tamminga et al., 1983), probably as a result of the defaunating effect of the fat, as recently confirmed by Czerkawski and Clapperton (1984). Increased microbial $N$ yields in the rumen result in better animal performance under some conditions (Bird et al., 1979 ; Demeyer et al., 1982), but animal response depends on the multiple interrelated effects of defaunation such as :

- inhibition of rumen fibre degradation (Demeyer, 1981);

- increase in fractional particle passage rate (Kayouli et al., 1983/84);

- inhibition of rumen protein degradation (Kayouli et al., 1983) ;

Reproduction, Nutrition, Développement, $\mathrm{n}^{\circ} 1$ B-86. -4 
- inhibition of rumen methanogenesis (Whitelaw et al., 1984a)

- elimination of protozoal contribution to duodenal microbial protein normally ranging between 0.14 and 0.55 (Demeyer and Vervaeke, 1984) ;

- lowered microbial incorporation of higher unsaturated fatty acids (Demeyer et al., 1978).

\subsection{Compartmentation and differential retention of microbes. - Czerkawski} (1984) an Owens and Goetsch (1984) distinguish three rumen compartments referred to here as $A, B$ and $C$ with particle dimensions of $<200 \mu$, between 200 and $1200 \mu$, and $>1200 \mu$, respectively. Microbes in A and $B$ leave the rumen at respective fractional rates $k_{A}$ and $k_{B}$, whereas microbes in $C$ do not leave the rumen (Owens and Goetsch, 1984). Their retention with associated lysis and recycling within $\mathrm{C}$ may be necessary for maximal fibre degradation as suggested for bacteroides (Cheng et al., 1983/84). It is clear that $k_{m}=C_{A} k_{A}+C_{B} k_{B}$, where $C_{A}$ and $C_{B}$ represent the proportion of total microbes in $A$ and $B$, respectively IOldham, 1984).

A more general equation states $k m=\Sigma C_{i} k_{i}$, where $C$ and $k$ are the proportion of microbes and the fractional outflow rate, respectively, of $i$ compartments. This complexity is further increased by changes in $C$ and $k$ with time after feeding because of decreasing particle size with progressive digestion and changes in saliva flow. Compartment $B$ may serve as a transport or shuttle compartment between $A$ and $C$ (Czerkawski, 1984). Within each compartment, $E$ increases with $k$ following the Pirt-Stouthamer model, but $k_{m}$ is obviously determined by the magnitude of $C_{A}$ and $k_{A}$ relative to $C_{B}$ and $k_{B}\left(e . g\right.$. an increase in $k_{B}$ may be offset by a decrease in $k_{A}$ and $C_{B} / C_{A}$ ). In continuous cultures, bacterial growth rate $(\mu)$ equals $k_{1}$ or the dilution rate (D) and their increase augments $E$ (fig. 2). Similar relations between $k_{1}$ and $E$ hold for the rumen, when particle $\left(k_{p}\right)$ and liquid $\left(k_{1}\right)$ fractional outflow rates are similar in the relatively large compartments $A$ and $B$. Such conditions are found when ground and pelleted or concentrate-rich diets are fed continuously (Kennedy et al., 1976 ; Kennedy and Miligan, 1978 ; Harrison et al, 1975) (fig. 2). Fractional outflow rates of bacteria, reflecting bacterial growth rate, are lower than $k_{1}$ however and better approximated by $k_{p}$ when $k_{1}>k_{p} \approx \frac{k_{A}+k_{B}}{2}$.

Changes in $k_{p}$ should therefore affect $k_{m}$ more than changes in $k_{1}$, but also because $k_{p}<k_{1}$. Indeed, the hyperbolic relationship between $\mu$ and $\mathrm{E}$ predicts a greater response at low values of $\mu$ (Van Soest, 1982). Crawford et al. (1980) in their in vitro system determined the effect of independently varied $k_{1}$ (0.07-0.15) and $k_{p}(0.034-0.070)$ values on $E$, obtained using RNA as a microbial marker. Recalculation of their data after correction for dietary RNA contamination $(0.15$ of RNA) (Smith, 1979) allows calculation of the regression equation $E=-49+965 k_{p}+423 K_{1}\left(n=9, R^{2}=0.73\right)$ in line with the relative importance of $k_{p}$ and $k_{1}$.

With high-concentrate or ground and pelleted diets rumination and salivation is reduced, resulting in lower $k_{1}$ values. Small feed-particle size on the other hand increases $k_{p}$. Whereas microbes present in compartments $B$ and $C$ or in the 
rumination pool (Hungate et al., 1971) turn over much more slowly than $k_{1}$ in roughage-fed animals, this difference may diminish when concentrates or ground and pelleted diets are fed continuously (Faichney and Griffiths, 1978). With larger feed-particle size and lower feeding frequency, as in animals fed chopped or long roughage twice daily, $k_{l}$ is very different from $k_{p}$ and there is no apparent relation between $E$ and $k_{p}$ or $k_{1}$ (Kennedy et al., 1982 ; Mathers and Miller, 1981; Hadjipanayiotou et a/ 1982). In roughage-fed animals however, a major part of the microbial matter, including protozoa, is associated with slow turnover in a large compartment $C$. Compartments $A$ and $B$ show rapid and thus efficient growth, with small particles continuously supplied from an efficiently drained compartment $C$. Because of the fibrous nature of the substrate growth in $C$ is slow, resulting in low $E$ values, also because protozoa are present. This may be balanced however by an energetically efficient acetate-type fermentation and the provision of necessary peptides and other growth factors by extensive recycling. It would seem that overall microbial $N$ yield in the animal benefits from the increased rumen compartmentation with roughage diets (table 1), in spite of the lower growth yields with fibrous substrates within one compartment (table 3 ). Fractional outflow rates of forage $\left(k_{f}\right)$ and concentrate $\left(k_{c}\right)$ particles, as affected by level of intake with high and low-forage diets, were determined by Colucci et al. (1982). Table 5 shows that level of intake affects $k_{c}$ more with low-forage (high-concentrate) diets than it does $k_{f}$ with high-forage (low-concentrate) diets. Similar effects were also reported by Owens and Goetsch (1984) and Van Vuuren (1984).

\section{TABLE 5}

Effect of diet and intake level on rumen retention of forage and concentrate particles ${ }^{1}$.

\begin{tabular}{lccc}
\hline Diet & $\begin{array}{c}\text { Level of } \\
\text { intake }\end{array}$ & \multicolumn{2}{c}{$\begin{array}{c}\text { Fractional outflow rate (k) of } \\
\text { Forage }^{2}\end{array}$} \\
\hline \multirow{2}{*}{ Low-forage } & Low & 0.023 & 0.038 \\
High-forage & High & 0.041 & 0.070 \\
& Low & 0.041 & 0.053 \\
\hline
\end{tabular}

1 From Colucci et al. (1982) ; ${ }^{2}$ Determined using Cr-mordanted material.

Such data help to explain contradictory results on the effects of level of feeding on microbial $N$ yield (table 1): increased level of feeding would be expected to increase $k_{p}$, and thus $\mu$ and $E$, with concentrate diets, as found by Zinn and Owens (1983). With mixed diets, an opposite effect was reported (Tamminga, 1978). In general, it would seem that increased duodenal flow is associated with higher vields of microbial N (Teller and Godeau, 1984 ; Zinn and Owens, 1983a).

\section{Conclusion.}

It is hypothesized (Demeyer and Vervaeke, 1984) that microbial $\mathrm{N}$ yields in the rumen may vary between two extremes: 
1) Long particle retention time, extensive rumination and salivation and high liquid turnover rates associated with long roughage feeding : net microbial $N$ yield is depressed by extensive recycling of bacteria due to the presence of an active protozoal population sequestered in the particle phase. This is balanced however by an energetically efficient acetate-type bacterial fermentation.

2) Short particle retention time, less rumination and salivation and low rumen liquid turnover associated with concentrate (starch) feeding : net microbial $\mathrm{N}$ yield is enhanced by the absence of protozoa, resulting in the presence of a fast growing flora. This is balanced however by an energetically less efficient propionatelactate type bacterial fermentation.

An optimal situation, occurring when feeding mixed diets, is associated with a mean microbial $\mathrm{N}$ yiels of $35 \mathrm{gN}_{\mathrm{i}} / \mathrm{kg} \mathrm{OM}$.

jères Journées sur la Nutrition et l'Alimentation des Herbivores, I.N.R.A., Paris, 21 et 22 mars 1985.

\section{References.}

AMOS H. E., EVANS J., 1976. Supplementary protein for low quality Bermudagrass diets and microbial protein synthesis. J. anim. Sci. 43, 861-868.

ARMSTRONG D. G., 1980. Net efficiencies (in vivo) of micorbial $N$ synthesis in ruminant livestock. Proc. $3^{r d}$. EAAP Symp. Protein metabolism and nutrition, Braunschweig, vol. 2. 400-411.

BEN-GHEDALIA D., McMENIMAN N. P., ARMSTRONG D. G., 1978. The effect of partially replacing urea nitrogen with protein $\mathrm{N}$ on $\mathrm{N}$ capture in the rumen of sheep fed a purified diet. Br. J, Nutr., 39, 37-44.

BIRD S. H., HILL M. K., LENG R. A., 1979. The effects of defaunation of the rumen on the growth of lambs on low-protein-high-energy diets. Br. J. Nutr, 42, 81-87.

BRANDT M., ROHR K., LEBZIEN P., 1981. Beitrage zur quantifizierung der N-Umsetzungen in den Vormagen von Milckkühen 2 Mitteilung. Ztschr. Tierphysiol. Tierernähr. Futtermittelk., 46. 49-59.

CHAMBERLAIN D. G., THOMAS P. C., 1979. Ruminal N metabolism and the passage of amino acids to the duodenum in sheep receiving diets containing hay and concentrates in various proportions. J. Sci. Fd. Agric., 30, 677-686.

CHAMBERLAIN D. G., THOMAS P. C., 1980. Protein digestion in cows and sheep given silage diets. Proc. $3^{\text {d }}$ EAAP Symp. Protein metabolism and nutrition, Braunschweig, vol. 2, 422-431.

CHENG K. I., AKIN D. E., COSTERTON G. W., 1977. Rumen bacteria : interaction with particulate dietary components and response to dietary variation. Fed. Proc., 36, 193-197.

CHENG K.-J., COSTERTON J. W., 1979. Adherent rumen bacteria-their role in the digestion of plant material, urea and epithelial cells, 227-250. In RUCKEBUSCH Y., THIVEND P., Digestive physiology and metabolism in ruminants, MTP Press Ltd, Falcon House.

CHENG K. J., STEWART C. S., DINSDALE D., COSTERTON J. W., 1983/84. Electron microscopy of bacteria involved in the digestion of plant cell walls. An. Feed. Sci. Technol., 10, 93-120.

COLEMAN G. S., 1979. The role of rumen protoza in the metabolism of ruminants given tropical feeds. Trop. anim. Prod., 4, 199-213.

COLEMAN G. S., SANDFORD D. C., 1979. The engulfment and digestion of mixed rumen bacteria and individual bacterial species by single and mixed species of rumen ciliate protozoa grown in vivo. J. agr. Sci, 92, 729-742.

COLUCCI P. E., CHASE L. E., VAN SOEST P. J., 1982. Feed intake, apparent diet digestibility and rate of particulate passage in dairy cattle. J. Dairy Sci., 65, 1445-1456.

COTTA M. A., RUSSELL J. B., 1982. Effect of peptides and amino acids on efficiency of rumen bacterial protein synthesis in continuous culture. J. Dairy Sci, 65, 226-234. 
COTTRILL B. R., BEEVER D. E., AUSTIN A. R., OSBOURN D. F., 1982. The effect of protein- and non-protein-nitrogen supplements to maize silage on total amino acid supply in young cattle. Br. J. Nutr., 48, 527-541.

CRAWFORD R. J. Jr., HOOVER W. H., KNOWLTON P. H., 1980. Effects of solids and liquid flows on fermentation in continuous cultures. I. Dry matter and fiber digestion, VFA production and protozoa numbers. J. anim. Sci, 51, 975-985.

CUMMINS K. A., WOCEK J. E., POLAN C. E., HERBEIN J. H., 1983. Nitrogen degradability and microbial protein synthesis in calves fed diets of varying degradability defined by the bag technique. J. Dairy Sci, 66, 2356-2364.

CZERKAWSKI J. W., 1984. Microbial fermentations in the rumen. Proc. Nutr. Sco., 43, 101-118.

CZERKAWSKI J. W., CLAPPERTON J. L., 1984. Fats as energy-yielding compounds in the ruminant diet, 249-263. In J. WISEMAN, Fats in animal nutrition. Butterworths, London.

DEMEYER D., 1973. Lipidstoffwechsel im Pansen, 209-234. In GIESECKE D., HENDERICKX H., Biochemie und Biochemie der Mikrobiellen Verdauung, BLV Verslaggesellschaft, München.

DEMEYER D. I., 1981. Rumen microbes and digestion of plant cell walls. Agric. Environm., 6, 295337.

DEMEYER D. I., VAN NEVEL C. J., 1975. Metanogenesis, an integrated part of carbohydrate fermentation, and its control, 366-382. In I. W. McDonald and A.C.I. WARNER, Digestion and metabolism in the ruminant. Proc. $4^{\text {th }}$ int. Symp. Ruminant physiology. The Univ. of New England Publ. Unit.

DEMEYER D. I., VAN NEVEL C. J., 1975a. Rumen fermentation pattern and efficiency of microbial growth. Misc. Papers Landbouwhogeschool Wageningen, 11, 31-32.

DEMEYER D., VAN NEVEL C., 1976. A critical approach to isotope methods for measuring microbial growth in the rumen in vitro, 63-68. In Tracer studies on NPN for ruminants, III, IAEA, Vienna.

DEMEYER D., VAN NEVEL C., 1978. Bepaling van niet-eiwit stikstof (NEN) benutting in de pens en evaluatie vaneen NEN bron. Landbouwtijdschrift, 31, 1095-1104.

DEMEYER D., VAN NEVEL C., 1979. Protein fermentation and growth by rumen microbes. Ann. Rech. vét., 10, 275-279.

DEMEYER D. I., VAN NEVEL C. J., 1979a. Effect of defaunation on the metabolism of rumen micro-organisms. Br. J. Nutr. 42, 515-524.

DEMEYER D. I., VAN NEVEL C. J., 1980. Nitrogen exchanges in the rumen. Proc. Nutr. Soc., 39, 89-95.

DEMEYER D. I., VERVAEKE I., 1984. Rumen digestion and microbial processes for increasing the feed value of poor quality materials. Proc. OECD Workshop on Improved utilisation of lignocellulose materials with special reference to animal feed. Braunschweig, (in press).

DEMEYER D. I., VAN NEVEL C., HENDERSON C., 1972. Stoichiometry of $\mathrm{O}_{2}$ utilization by rumen contents. Proc. $2^{\text {nd }}$ WId. Congr. Anim. Feed. Madrid, 5, 33-37.

DEMEYER D. I., HENDERSON C., PRINS R. A., 1978. Relative significance of exogenous and de novo synthesized fatty acids in the formation of rumen microbial lipids in vitro. Appl. environ. Microbiol., 35. 24-31.

DEMEYER D. I., VAN NEVEL C. J., VAN DE VOORDE G., 1982. The effect of defaunation on the growth of lambs fed three urea-containing diets. Arch. Tierernähr., 32, 595-604.

DEMEYER D. I., VAN NEVEL C. J., VERMANDER C., FAQUAET M., 1984. Het effect van $\mathrm{O}_{2}$ op het groeirendement van pens-microben in vitro. Proc $9^{\circ}$ Studiedag Voeding, Utrecht, 13-15.

DURAND M., 1982. Orientation du métabolisme du rumen au moyen des additifs. Ann. Zootech., 31, 47-76.

EADIE G. M., HYLDEGAARD-JENSEN G., MANN S. O., REID R. S., WHITELAW F. G., 1970. Observations on the microbiology and biochemistry of the rumen in cattle given different quantities of a pelleted barley ration. Brit. J. Nutr. 24, 157-177.

EGAN A. R. 1974. Protein-energy relationships in the digestion products of sheep fed on herbage diets differing in digestibility and nitrogen concentration. Austr. J. Agr. Res., 25, 613-630.

ELLIOTT R., ARMSTRONG D. G., 1982. The effect of urea and urea plus sodium sulphate on microbial protein production in the rumens of sheep given diets high in alkali-treater barley straw $J$. agric. Sci., 99, 51-60. 
ERFLE J. D., SAUER F. D., MAHADEVAN S., 1984. Energy metabolism in rumen microbes. Proc. $6^{\text {th }}$ int. Symp. Rumin. Physiol., Banff (in press).

FAICHNEY G. J., 1975. The use of markers to partition digestion within the gastro-intestinal tract of ruminants, 277-291. In I. W. McDONALD and A. C. 1. WARNER. Digestion and metabolism in the ruminant. Proc. IV int. Symp. on Ruminant Physiology. The Univ. of New England Publ. Unit.

FAICHNEY G. J., GRIFFITHS D. A., 1978. Behaviour of solute and particle markers in the stomach of sheep given a concentrate diet. Br. J. Nutr., 40, 71-81.

HADJIPANAYIOTOU M., HARRISON D., ARMSTRONG D., 1982. The effects upon digestion in sheep of the dietary inclusion of additional salivary salts. J. Sci. Fd. Agric., 33, 1057-1062.

HAGMEISTER H., LUPPING W., KAUFMANN W., 1981. Microbial protein synthesis and digestion in the high-yielding dairy cow, 31-48. In W. HARESIGN and D. S. A. COLE. Recent development in ruminant nutrition. Butterworths, London.

HARMEYER J., GULDENHAUPT H., 1980. Measurements of protein turnover in batch cultures of rumen microbes using isotopic markers. Proc. $3^{r^{\prime}}$ EAAP Symp. Protein Metabolism Nutrition, Braunschweig, vol. 1, 49-55.

HARMEYER J., MARTENS M., BREVERS G., HOLLER M., 1981. Microbial protein synthesis in the rumen of an autochthonous sheep breed (heidschnüken) fed unconventional diets, 3033. In D. GIESECKE, G. DIRKSEN and M. STAGASSINGER, Metabolic disorders in farm animals. Proc. $4^{\text {th }}$ int. Conf. Prod. Dis. Farm Anim., Müchen (1980). Fotodruck Frank OHG, München.

HARRISON D. G., MCALLAN A. B., 1980. Factors affecting microbial growth yields in the reticulo-rumen, 205-226. In Y. RUCKEBUSCH and P. THIVEND. Digestive physiology and metabolism in ruminants, MTP Press Limited, Falcon House.

HARRISON D. G., BEEVER D. E., THOMSON D. J., OSBOURN D. F., 1975. Manipulation of rumen fermentation in sheep by increasing the rate of flow of water from the rumen J. agr. Sci., 85 , 93-101.

HART F. J., ORSKOV E. R., 1979. Effect of type of carbohydrate on the production of microbial $\mathrm{N}$ in the rumen. Proc. Nutr. Soc., 38, 130A.

HESPELL R. B., 1979. Efficiency of growth by ruminal bacteria. Fed. Proc., 38, 2707-2712.

HESPELL R. B., 1983. Influence of ammonia assimilation pathways and survival strategy on ruminal microbial growth, 346-358. In F. M. C., GILCHRIST, MACKIE R. I., Herbivore nutrition in the subtropics and tropics. The Science Press, Johannesburg.

HESPELL R. B., BRYANT M. P., 1979. Efficiency of rumen microbial growth: influence of some theoretical and experimental factors on $\mathrm{Y}_{\text {ATP. }}$ J. anim. Sci, 49, 1640-1659.

HOBSON P. N., WALLACE R. J., 1982. Microbial ecology and activities in the rumen part II. C.R.C. Crit. Rev. Microbiol, 9, 253-320.

HOOVER W. H., CRAWFORD R. J. jr., STERN M. D., 1982. Effects of solids and liquid flows on fermentation in continous culture. III. solids rentention time. J. anim. Sci., 54, 849-854.

HOOVER W. H., KINCAID C. R., VARGA G. A., THAYNE W. V., JUNKINS L. L., 1984. Effects of solids and liquid flows on fermentation in continuous cultures: IV. $\mathrm{pH}$ and dilution rate. $J$. anim. Sci, 58, 692-699.

HUME I. D., 1970. Synthesis of microbial protein in the rumen. 3. The effect of dietary protein. Austr. J. agric. Res., 21, 305-314.

HUNGATE R. E., 1963. Symbiotic associations: the rumen bacteria. Symp. Soc. gen. Microbiol, 8, 266-297.

HUNGATE R. E., REICHL J., PRINS R., 1971. Parameters of rumen fermentation in a continuously fed sheep : Evidence of a microbial rumination pool. Appl. Microb., 22, 1104-1113.

HVELPLUND T., MOELLER P. D., 1978. Nitrogen metabolism in the rumen of re-entrant fistulated cows fed rations of ammoniatreated straw or sugar beets. Proc. $3^{\text {rd }}$ World Congr. anim. Feed, Madrid, vol. 8, 26.

ISAACSON H. R., HINDS F, C., BRYANT M. P., OWENS F. N., 1975. Efficiency of energy utilization by mixed rumen bacteria in continuous culture. J. Dairy Sci., 58, 1645-1659.

JARRIGE R., JOURNET M., VÉRITÉ R., 1978. Azote, 89-128. In /'Alimentation des ruminants. INRA, Versailles. 
JOHNSON R. R., 1976. Influence of carbohydrate solubility on non-protein nitrogen utilization in the ruminant. $J$. anim. Sci., 43, 184-191.

JOUANY J. P., 1978. Contribution à l'étude des protozaires ciliés du rumen: leur dynamique, leur rôle dans la digestion et leur intérêt pour le ruminant. Th. Doctorat, Univ. ClermontFerrand II.

KAYOULI C., VAN NEVEL C., DEMEYER D., 1983. Effet de la défaunation du rumen sur la dégradabilité des protéines du soja mesurée " in sacco ". $4^{\text {th }}$ int. Symp. Protein Metabolism and nutrition., Clermont-Ferrand vol. II, INRA ed., 251-259.

KAYOULI C., DEMEYER D. I., VAN NEVEL C. J., DENDOOVEN R., 1983/84. Effect of defaunation on straw digestion in sacco and on particle retention in the rumen. Anim. Feed Sci. Technol. 10, 165-172.

KENNEDY P. M., 1982. Ruminal and intestinal digestion in Brahman crossbred and Hereford cattle fed alfalfa or tropical pasture hay. J. anim. Sci., 33, 1190-1199.

KENNEDY P. M., MILLIGAN L. P., 1978. Effects of cold exposure on digestion, microbial synthesis and nitrogen transformations in sheep. Br. J. Nutr., 39, 105-117.

KENNEDY P. M., CHRISTOPHERSON R. J., MILLIGAN L. P., 1976. The effect of cold exposure of sheep on digestion, rumen turnover time and efficiency of microbial synthesis. Br. J. Nutr., 36, 231-241.

KENNEDY P. M., CHRISTOPHERSON R. J., MILLIGAN L. P., 1982. Effect of cold exposure on feed protein degradation, microbial protein synthesis and transfer of plasma urea to the rumen of sheep. Br. J. Nutr., 47, 521-535.

KROPP J. R., JOHNSON R. R., MALES J. R., OWENS F. N., 1977. Microbial protein synthesis with low quality roughage rations : isonitrogenous substitution of urea for soya bean meal. J. anim. Sci., 46, 837-843.

KROPP J. R., JOHNSON R. R., MALES J. R., OWENS F. N., 1977a. Microbial protein synthesis with low quality roughage rations. J. anim. Sci, 46, 844-854.

KURIHARA $Y$., TAKECHI T., SHIBATA F., 1978. Relationship between bacteria and ciliate protozoa in the rumen of sheep fed on a purified diet. J. agric. Sci., 90, 373-381.

LENG R. A., 1982. Dynamics of protozoa in the rumen of sheep. Br. J. Nutr., 48, 399-415.

LENG R. A., NOLAN J. V., 1984. Nitrogen metabolism in the rumen. J. Dairy Sci,, 67, 1072-1089.

LING J. R., BUTTERY P., 1978. The simultaneous use of ribonucleic acid, ${ }^{35} \mathrm{~S}, 2,6$-diaminopimelic acid and 2-aminoethylphosphonic acid as markers of microbial nitrogen entering the duodenum of sheep. Br. J. Nutr., 39, 165-179.

LING J. R., SWAN H., BUTTERY P. J., 1983. Interrelationships in the digestion of sheep given barley grain diets containing either fish meal, soyabean meal or urea. Arch. Tierernähr., 10/11, 793-804.

LYLE R. R., JOHNSON R. R., WILHITE J. V., BACHUS W. R., 1981. Ruminal characteristics in steers as affected by adaptation from forage to all concentrate diets. J. anim. Sci., 53, 1383-1390.

MAENG W. I., VAN NEVEL C. J., BALDWIN R. L., MORRIS J. G., 1976. Rumen microbial growth rates and yields : effect of amino acids and protein. J. Dairy Sci., 59, 68-79.

MATHERS J. C., MILLER E. L., 1981. Quantitative studies of food protein degradation and the energetic efficiency of microbial protein synthesis in the rumen of sheep given chopped lucerne and rolled barley. Br. J. Nutr., 45, 587-604.

MCALLAN A. B., SMITH R. H., 1983. Estimations of flows of organic matter and nitrogen components in postruminal digesta and effects of level of dietary intake and physical form of protein supplement on such estimates. Br. J. Nutr., 49, 119-127.

MCALLAN A. B., SMITH R. H., 1984. The efficiency of microbial protein synthesis in the rumen and the degradability of feed nitrogen between mouth and abomasum in steers given different diets. Br. J. Nutr., 51, 77-83.

MEGGISON P. A., McMENIMAN N. P., ARMSTRONG D. G., 1979. Efficiency of microbial protein synthesis in cattle. Proc. Nutr. Soc., 38, 146A.

MERCER J. R., ALLEN S. A., MILLER E. L., 1980. Rumen bacterial protein synthesis and the proportion of dietary protein escaping degradation in the rumen of sheep. Br. J. Nutr., 43, 421-433. 
MOLLER P. D., HVELPLUND T., 1982. Nitrogen metabolism in the forestomachs of cows fed ammonia-treated barley straw supplemented with increasing amounts of urea or soya bean meal. Zeitschr. Tierphysiol. Tierernähr. Futtermittelkde, 48, 46-57.

OFFER N. W., AXFORD R. F. E., EVANS R. A., 1978. The effect of dietary energy source on nitrogen metabolism in the rumen of sheep. Br. J. Nutr., 40, 35-44.

OLDHAM J., 1984. Protein-energy interrelationships in dairy cattle. J. Dairy Sci., 67, 1090-1112.

OLDHAM J., SUTTON J. D., MCALLAN A. B., 1979. Protein digestion and utilization by dairy cows. Ann. Rech. vét., 10, 290-293.

OWENS F. N., GOETSCH A. L., 1984. Digesta passage and microbial protein synthesis. Proc. $6^{\text {in }}$ int. Symp. Rumin. Physiol., Banff, (in press).

REDMAN R. G., KELLAWAY R. C., LEIBHOLZ J., 1980. Utilization of low quality roughages : effects of urea and protein supplements of differing solubility on digesta flows, intake and growth rate of cattle eating oaten chaff. Br. J. Nutr., 44, 343-354.

ROY J. H. B., BALCH C. C., MILLER E. L., ORSKOV E. R., SMITH R. H., 1977. In S. TAMMINGA, Proc. $2^{\text {nd }}$ int. Symp. Prot. Met. Nutr. PUDOC, Wageningen, 1267-129.

RUSSEL J. B., HESPELL R. B., 1981. Microbial rumen fermentation. J. Dairy Sci, 64, 1153-1165.

RUSSELL J. B., SNIFFEN C. J., VAN SOEST P. J., 1982. Effect of carbohydrate limitation on degradation and utilisation of casein by mixed rumen bacteria. J. Dairy Sci., 66, 763-775.

SATTER L. D., ROFFLER R. E., 1981. Influence of nitrogen and carbohydrate inputs on rumen fermentation, 115-139. In W. HARESIGN and D. J. COLE. Recent developments in ruminant nutrition, Butterworths, London.

SCOTT R. I., YARLETT N., HILLMAN K., WILLIAMS T. N., WILLIAMS A. G., LLYOD D., 1983. The presence of $\mathrm{O}_{2}$ in rumen liquor and its effects on methanogenesis. J. appl. Bact., 53, $143-149$.

SILLEY P., ARMSTRONG D. G., 1984. Changes in metabolism and cell size of the anaerobic bacterium Selenomonas ruminantium $0078 \mathrm{~A}$ at the onset of growth in continuous culture. $J$. appl. Bact., 56, 487-492.

SMITH R. H., 1979. Synthesis of microbial nitrogen compounds in the rumen and their subsequent digestion. J. anim. Sci. 49, 1604-1614.

SMOUSE P. E., 1981. Mathematical models for continuous culture growth dynamics of mixed populations subsisting on a heterogeneous resource base. II, predation and trophic structure. Theor. Popul. Biol., 20, 127-149.

STERN M. D., HOOVER H., SNIFFEN C. J., CROOKER B. A., KNOWLTON P. H., 1978. Effects of non structural carbohydrate, urea and soluble protein levels on microbial protein synthesis in continuous culture of rumen contents. J. anim. Sci., 47, 944-956.

STOUTHAMER. A. H., BETTENHAUSSEN C. W., 1973. Utilization of energy for growth and maintenance in continuous and batch cultures of micro-organisms. A re-evaluation of the method for the determination of ATP production by measuring molar growth yields. Biochim. Biophys. Acta, 301, 53-70.

SUTTON J. D., 1979. Carbohydrate fermentation in the rumen : variations on a theme. Proc. Nutr. Soc., 38, 275-281.

TAMMINGA S., 1978. Measurement of microbial protein synthesis in the rumen, 5.1-5.13. In D. F. OSBOURN, D. E. BEEVER, D. J. THOMSON. Ruminant digestion and feed evaluation. A.R.C. London.

TAMMINGA S., 1979. Relation between different carbohydrates and microbial synthesis of protein. In Kiel group seminar. Uppsala. Report $n^{\circ} 130$, Hoorn Institute, Lelystad, Netherlands.

TAMMINGA S., 1980. Energy-protein relationships in ruminant feeding : similarities and differences between rumen fermentation and post ruminal utilization, 2-17. In MILLER E. L. PIKE I. M. Protein contribution of feedstuffs for ruminants Proc. $5^{\text {th }}$ int. Symp. Fish. Meal Manuf., Butterworth, Amsterdam, London.

TAMMINGA S., 1981. Effect of the roughage/concentrate ratio on $\mathrm{N}$ entering the small intestine of dairy cows. Neth. J. agric. Sci., 29, 273-283.

TAMMINGA S., 1983. Recent advances in our knowledge on protein digestion and absorption in ruminants. Proc. $4^{\text {th }}$ Symp. Prot. Met. Nutr., Clermont-Ferrand, INRA Publ., Coll. INRA ${ }^{\circ}$ 16 , vol. I, 263-287. 
TAMMINGA S., VAN VUUREN A. M., VAN DER KOELEN C. J., KNATTAB H. M., VAN GILS G. M., 1983. Further studies on the effect of fat supplementation of concentrates fed to lactating dairy cows. 3. Effect on rumen fermentation and site of digestion of dietary components. Neth. J. agric. Sci, 31, 249-258.

TELLER E., GODEAU J. M., 1984. Some observations about the efficiency of bacterial protein synthesis in the rumen of cattle. Z. Tierphysiol. Tierernährg. Futtermittelkde., 51, 268-274.

THAUER R. K., KRÖGER A., 1983. Energy metabolism of two rumen bacteria with special reference to growth efficiency, 399-407. In F. M. C. GILCHRIST, MACKIE R. I., Herbivore nutrition in the subtropics and tropics, The Science Press, Johannesburg.

THAUER R. K., JUNGERMANN K., DECKER K., 1977. Energy conservation in chemotrophic anaerobic bacteria. Bact. Rev., 41, 100-180.

USHIDA K., JOUANY J. P., LASSALAS B., THIVEND P., 1984. Protozoal contribution to nitrogen digestion in sheep. Can. J. anim. Sci., 64, 20-21.

VAN NEVEL C. J., DEMEYER D. I., 1977. Determination of rumen microbial growth in vitro from 32 P-labelled phosphate incorporation. Br. J. Nutr., 38, 101-114.

VAN NEVEL C. J., DEMEYER D. I., 1979. Stoichiometry of carbohydrate fermentation and microbial growth efficiency in a continious culture of mixed rumen bacteria. Eur. J. appl. Microbiol. Biotechnol., 7, 111-120.

VAN NEVEL C. J., DEMEYER D. I., 1981. Effect of methane inhibitors on the metabolism of rumen microbes in vitro. Arch. Tierernähr., 31, 141-151.

VAN NEVEL C. J., DEMEYER D., 1983. Beschouwingen omtrent de microbiële eiwitsynthese in de pens. Landbouwtijdschr., 36, 1169-1190.

VAN NEVEL C. J., DEMEYER D. I., HENDERICKX H. K., 1972. Stoichiometry of fermentation of soluble carbohydrates by mixed rumen micro-organisms. Proc. $2^{\text {nd }}$ WId. Congr. anim. Feed., Madrid, 5, 27-31.

VAN SOEST P., 1982. Nutritional ecology of the ruminant. O \& B Books Inc., Corvallis, 152-177.

VAN VUUREN A. M., 1984. Effect of level of hay intake, method of marker administration and stage of lactation on rate of passage through the reticulorumen. Can. J. anim. Sci, 64, 8081.

WHITELAW F. G., EADIE M., BRUCE L. A., SHAND W. J., 1984. Microbial protein synthesis in cattle given roughage-concentration and all-concentrate diets : the use of 2,6 diaminopimelic acid, 2-aminoethylphosphonic acid and ${ }^{35} \mathrm{~S}$ as markers. Br. J. Nutr., 52, 249-260.

WHITELAW F. G., EADIE M., BRUCE L. A., SHAND W. J., 1984a. Methane formation in faunated and ciliate-free cattle and its relationship with rumen volatile fatty acid proportions. $B r . J$. Nutr., 52, 261-275.

WILLIAMS A. G., WITHERS S. E., 1983. Bacillus spp. in the rumen ecosystem : hemicellulose depolymerases and glycoside hydrolases of Bacillus spp. and rumen isolates grown under anaerobic conditions. J. appl. Bact., 55, 283-292.

WOLIN M. J., 1979. The rumen fermentation : a model for microbial interactions in anaerobic systems. In ALEXANDER M. ed. Adv. Microb. Ecol., vol. 3, 49-77. Plenum Press, New-York.

WOLIN M. J., MILLER T. L., 1983. Interactions of microbial populations in cellulose fermentation. Fed. Proc., 42, 109-113.

ZINN R. A., BULL L. S., HEMKEN R. W., 1981. Degradation of supplemental proteins in the rumen. J. anim. Sci, 52, 857-866.

ZINN R. A., OWENS F. N., 1983. Influence of feed intake level on site of digestion in steers fed a high concentrate diet. J. anim. Sci, 56, 471-475.

ZINN R. A., OWENS F. N., 1983a. Site of protein digestion in steers : predictability. J. anim. Sci., 56. 707-716. 